\title{
RC-UFBA: MAIS UM ESPAÇO PARA A PUBLICAÇÃO CIENTÍFICA
}

Partindo do princípio de que a comunicação é elemento indispensável ao desenvolvimento da atividade científica, até porque sem esse recurso não seria possível a soma de esforços individuais de pesquisadores, professores, alunos e outros agentes vinculados à produção do saber, a Faculdade de Ciências Contábeis da UFBA acaba de instituir a sua Revista de Contabilidade. Esta iniciativa está fundamentada na idéia de que o saber acadêmico é patrimônio de toda a sociedade e, como tal, deve ser comunicado por meio do ensino, da publicação e por outras formas disponíveis. A criação deste veículo expressa, portanto, a consciência de que temos o dever de produzir e difundir conhecimentos que contribuam para a promoção do bem-estar da humanidade e, particularmente, para a melhoria das condições de vida da população baiana.

Esta Revista pretende ser um espaço em que pesquisadores, professores e alunos possam apresentar a sua produção à comunidade acadêmica, interagir com seus pares, receber críticas e sugestões, formar grupos de estudo, ampliar discussões, articular-se com outras instituições de ensino, enfim, favorecer iniciativas que contribuam para o avanço do saber. De igual forma, esperamos que este periódico possa funcionar também como instrumento de atualização de alunos e professores nos mais diferentes rincões do País, evitando, assim, que a difusão dos conhecimentos aqui produzidos fique restrita aos muros da própria Faculdade. A escassez de canais adequados para a publicação científica fortalece a esperança de que realmente possamos fornecer a estudantes e professores da área contábil subsídios para a realização de monografias, artigos, dissertações, teses e outros trabalhos do gênero.

Finalmente, desejamos registrar que a criação deste periódico materializa um sonho de todos que integram o Departamento de Contabilidade da UFBA. Mas é preciso salientar também que este sonho não teria se concretizado sem o esforço e o compromisso de cada indivíduo que constrói, em seu cotidiano, a própria história da Faculdade de Ciências Contábeis. Como exemplo, merecem destaque as ações que resultaram no fortalecimento do programa de pósgraduação, na implantação do Mestrado em Contabilidade, no fortalecimento da titulação do quadro docente e na expansão da produção científica. Sem dúvidas, tudo isso contribuiu para reforçar a massa crítica disponível e aguçar a sede de oferecer à comunidade científica mais um mecanismo de divulgação do saber elaborado nesta e em outras instituições de ensino.

Se o acesso ao conhecimento é condição fundamental para o desenvolvimento socioeconômico, nutrimos a esperança de que esta pequena iniciativa possa contribuir para fortalecer as bases de uma sociedade mais justa, livre e solidária. Consignamos, nesta oportunidade, nossos melhores agradecimentos a todos que colaboraram na execução deste projeto, especialmente aos professores que, muito gentilmente, aceitaram nosso convite para integrar o corpo editorial. De igual forma, rendemos nossas homenagens aos colegas pesquisadores de diversas Universidades que, generosamente, cederam parte da sua produção científica para compor a primeira edição deste periódico.

José Maria Dias Filho Professor Doutor da Faculdade de Ciências Contábeis da UFBA 